\title{
SROI KÄYTÖSSÄ - SOCIAL RETURN ON INVESTMENT -ARVIOINTIMETODIN SOVELTAJAN MUISTIINPANOJA
}

\author{
Juha Klemelä: VTM, tobtorikoulutettava, Turun yliopisto \\ jklemela@utu.fi \\ Janus vol. 27 (2) 2019, $\mathrm{xxx}-\mathrm{xxx}$
}

Järjestöjä kiinnostaa toiminnan vaikuttavuuden taloudellistyyppinen mittaaminen. ${ }^{1}$ Social Return on Investment (SROI) eli investoinnin yhteisötuoton laskenta -metodi on arviointityökalu tähän tarkoitukseen. Sen avulla esimerkiksi sosiaali- ja terveysalan järjestöjen tuottamia ei-rahallisia hyötyjä voidaan rahallistaa ja suhteuttaa tuottamisen vaatimiin panoksiin.(Ks. Klemelä 2016; Nicholls ym. 2012.)

SROI-metodiin ja taloudelliseen mittaamiseen kohdistuvalla mielenkiinnolla on syynsä. Viime vuosien yhteiskunnalliset virtaukset ovat korostaneet kustannus-hyötytietoisuutta palvelutuotannossa. Suunnitteilla oleva soteuudistus luo erityispaineita sosiaali- ja terveysalan toimijoille, koska uudistusta siivittää ajatus palveluntuottajien välisestä markkinakilpailusta.

SROI-menetelmän käytön tarkoituksena ei ole väittää laadullisia asioita määrällisiksi tai redusoida sosiaalista taloudelliseksi, vaan toimia mekanismina, jonka avulla "pehmeiden" hyötyjen rahanarvoisuus saadaan näkyväksi. SROI ei ole tulosautomaatti eikä tieteellinen metodi. Sen käyttö ei ole matemaattisen täsmällistä - niin kuin ei minkään arviointivälineen. SROI on pikemminkin käsityötä ja taito, jonka oppimisessa auttavat menetelmän käytön mallitapauksiin tutustuminen ja me- netelmän omatoiminen soveltaminen. Myös SROIn lukeminen on taito - on ymmärrettävä, että laskelmat perustuvat usein hyvin vahvoihin oletuksiin, ja on osattava sen perusteella arvioida laskelmien osuvuutta ja realistisuutta.

Jos toimijan ja soveltajan kannalta on kiinnostavaa, mitä SROI-menetelmällä voi tehdä, on menetelmässä viehätyksensä myös teoreettisemmin asennoituneen näkökulmasta. Taloudellisen ja sosiaalisen suhde on sosiaalitieteilijää aina kiinnostava kysymys. SROIn sekä siihen liittyvän terminologian ja välineistön tuntemus varustavat menetelmään tutustujan mielenkiintoisilla ja hänelle ehkä aivan uusilla välineillä tuon suhteen rajankäyntiin ja siitä keskusteluun.

Tässä puheenvuorossa esitetään kuvaus SROI-metodista empiirisessä käytössä. SROIn soveltamisesta on olemassa niukalti suomalaisia ja suomenkielisiä esimerkkejä. Potentiaaliset käyttäjät ja raporttien lukijatkin hyötyvät kuvauksista, joissa selitetään, millaisten vaiheiden, ongelmien ja ratkaisujen kautta oikeissa SROI-tapauksissa on edetty lopputulokseen. Kuvausten kirjoittaminen on hedelmällistä myös arviointitutkimuksen kehityksen kannalta. Kuvaukset tekevät mahdolliseksi syvemmän keskustelun siitä, mitkä ovat metodin edellytykset tuottaa uskottavaa tietoa. 


\section{ESIMERKKINÄ RATKO-MALLIN SROI}

Puheenvuorossa esitellään ja valaistaan SROI-menetelmän käyttöä Vamlassäätiön Ratko-mallin SROI-analyysin avulla (ks. Klemelä 2018). Vamlas tarkoittaa Vammaisten lasten ja nuorten tukisäätiötä. Ratko on valmennusmalli, joka on luotu vammaisten ja osatyökykyisten työllistämisen tueksi (Hietala ym. 2015,3). Ratko on lyhenne sanoista "ratkaisu erityistä tukea tarvitsevan työnhakijan ja työtehtävän kohtaamiseen" (Vamlas 2011). SROI-analyysi tehtiin vuoden 2017 kesän ja vuoden 2018 kevään välisenä aikana.

Vamlasin Ratko-kehittämisprojekti lähti liikkeelle havainnosta, että vammaisten ja osatyökykyisten nuorten avoimille työmarkkinoille työllistymistä tukeva toiminta oli puutteellista. Työhönvalmennus ja kuntouttava toiminta onnistuivat huonosti ihmisten töihin saamisessa ja siellä pitämisessä. Yksi syy tähän on voinut olla, että valmennus ja kuntoutus ovat keskittyneet työllistettävään henkilöön ja työpaik- koja, -tehtäviä ja -yhteisöjä ei ole otettu tarpeeksi huomioon. Ratkossa sen sijaan valmennetaan työnhakijan lisäksi myös työpaikkaa ja tämän seurauksena “työtehtävät hyödyntävät työyhteisön tavoitteita, työntekijä pystyy suoriutumaan tehtävistään ja työyhteisön ilmapiiri tukee osatyökykyisen työssä onnistumista". (Hietala ym. 2015, 5, 18-19.)

\section{SROIN VAIHEET JA PERIAATTEET}

SROI-menetelmä voidaan jakaa neljään vaiheeseen ja kymmeneen tehtävään (ks. Klemelä 2016). Vaiheet ja tehtävät on esitetty seuraavassa kuviossa (ks. kuvio 1). Vaikka tehtävät esitetään kuviossa tietyssä suoraviivaisessa ja selkeässä numerojärjestyksessä, käytännössä suorituksessa ja raportoinnissa on luontevaa poiketa kuvion esityksestä, koska monet tehtävistä voidaan suorittaa yhtäaikaisesti tai samat tehtävät voidaan suorittaa monta kertaa peräkkäin eri vaikuttavuustekijöiden kohdalla.

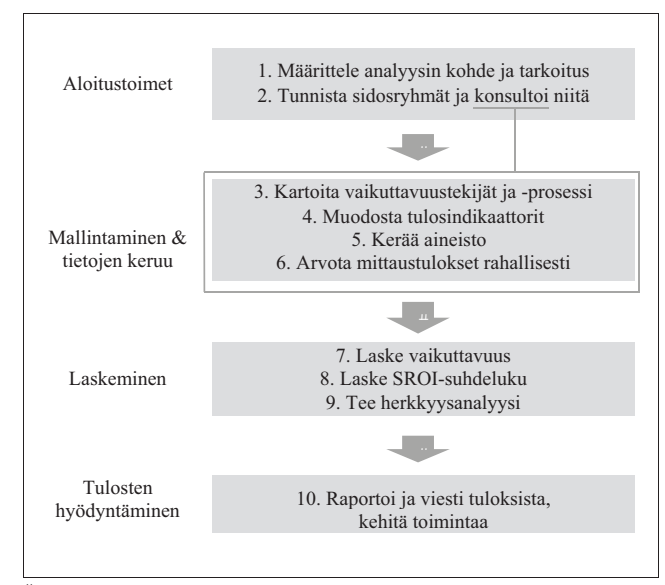

Kuvio 1. SROI-analyysin vaiheet ja 10 tehtävää (Klemelä 2016). 
SROI-analyysin keskeinen tulos on SROI-suhdeluku, joka kuvaa tarkasteltavan toiminnan tuottamien rahallistettujen hyötyjen ja toimintaan tehtyjen rahallistettujen investointien välistä suhdetta eli osamäärää. Kun hyödyt ovat täsmälleen investointien suuruiset, SROIsuhdeluvun arvo on yksi (1). SROIn käytön suurimpia haasteita on tehdä ja esittää analyysi siten, että suhdeluku sinällään ei varasta koko huomiota. On tärkeä ymmärtää, miten luku on laskettu ja mihin erilaisiin osatekijöihin ja ratkaisuihin luku perustuu.

\section{ANALYYSIIN LÄHTÖ: SROI-TIIMI APUUN}

SROI-työskentely aloitettiin tutustumalla huolellisesti niin Vamlas-järjestöön kuin Ratko-malliinkin liittyvään kirjalliseen aineistoon. Materiaalia saatiin sekä internetistä että Vamlasin työntekijöiltä. Erityisen hyödyllinen lähde alkuvaiheen työskentelyssä oli Ratkosta kehittämisprosessin aikana tehty tutkimus Kaikille sopiva työ ja työyhteisö (Hietala ym. 2015).

SROIn yhtenä tarkoituksena on tutustuttaa ja sitouttaa tarkasteltavan organisaation tai projektin toimijat ja sidosryhmät organisaation toimintaan. Organisaatiotoimijoiden sitouttamista varten, mutta myös itse SROI-mallin tekemistä varten, muodostettiin Vamlasissa SROI-tiimi. SROI-tiimi on työryhmä, joka paitsi valvoo SROIn suorittamista, myös hankkii SROI-analyysin tekijälle hänen tarvitsemaansa informaatiota sekä auttaa ja konsultoi erilaisten malliin liittyvien valintojen tekemisessä.

Tärkeä asia heti SROI-tiimin toiminnan alussa oli sidosryhmien kartoittaminen ja nimeäminen. Sidosryhmillä tarkoite- taan kaikkia niitä tahoja, jotka vaikuttavat tarkasteltavaan toimintaan, projektiin tai organisaatioon tai joihin tarkasteltava kohde vaikuttaa (ks. Freeman 1984, 46). Keskeisiä eli tärkeimpiä sidosryhmiä nimettiin 6 kappaletta:

1. kohderyhmä eli vammaiset ja osatyökykyiset, työllistymistarpeessa olevat nuoret ("ratkolaiset"),

2. käyttäjäorganisaatiot eli työllistävät tahot (Ratko-metodia käyttävien organisaatioiden johto ja työntekijät),

3. lähettäjäorganisaatiot eli organisaatiot (oppilaitokset ym.), joista potentiaaliset työllistetyt tulevat (edustajina näissä organisaatioissa työskentelevät työvalmentajat),

4. kehittäjätaho eli Vamlas (edustajina Vamlasissa työskentelevät Ratko-koordinaattorit ja fasilitaattorit),

5. asiakkaat eli tahot, joita Ratko-metodin käyttäjäorganisaatio palvelee sekä

6. julkinen sektori (kunta, valtio ja sosiaalivakuutusyhtiöt).

SROI-tiimiläisten tekemät työ - informaation hankkiminen ja antaminen sekä konsultoiminen SROIn eri vaiheissa - olivat varsin tärkeä osa analyysin sujumista. Suurempaankin aktiivisuuteen olisi toki ollut varaa. Tutkija jäi pohtimaan, miten SROI-tiimin saisi kiinteämmin mukaan työskentelyyn. SROI-tiimille esitetyt pyynnöt pohtia SROIhin liittyviä yksityiskohtaisia ja usein aika hankalaltakin tuntuvia operationalisointi- ja rahallistamiskysymyksiä saattoivat olla muun päivittäisen työn keskellä liian abstrakteja, kaukaisia 
ja työläitä, jotta niihin olisi ehtinyt tai halunnut reagoida. Ehkä olisi sittenkin pitänyt järjestää enemmän kokoontumisia ja käydä niissä aivoriihen tapaan läpi vaativimmat kysymykset.

\section{SROI-MALLINTAMINEN JA TARVITTAVAN INFORMAATION KERUU}

Ratko-metodin toiminnan mallintamiseen tarvittiin lisäinformaatiota ja tarkennusta sen ohelle, mitä Ratkosta selvisi kirjallisen ja internet-materiaalin pohjalta. Jo aloitettua analyysitiedon keruuta jatkettiin haastattelemalla ensin Ratkon kehittämisvaiheen Ratko-koordinaattorit. Haastattelujen tavoitteena oli saada syvempi perusymmärrys Ratkomenetelmän kehittämisen historiasta, menetelmän sisällöstä sekä menetelmän tavoitteista ja tarkoituksista. Koordinaattorien haastattelun jälkeen edettiin muiden sidosryhmien haastatteluihin.

SROI-menetelmän suoritusohjeet sekä osin kirjoittamaton menettelykulttuuri ovat osin ristiriidassa tiedonkeruun todellisuuden ja empiiristen vaatimusten välillä.Yksi asia, joka on jäänyt liian pienelle huomiolle, ovat tutkimusluvat. SROI-datan keruussakin voi olla sellaisia piirteitä, että sidosryhmäedustajia lähestyttäessä on tarpeellista tehdä asianmukaiset tutkimuslupahakemukset. Tämä pätee erityisesti silloin, kun kohteena on julkisia organisaatioita tai ihmisryhmiä, joiden asema on esimerkiksi sosiaalisesti tai terveydellisesti heikko. Tällöin esille nousevat myös tutkimuseettiset kysymykset, eikä niihinkään ole SROI-ohjeistuksissa kiinnitetty erityistä huomiota.
Tutkimuslupahakemusmenettelyt ovat usein raskaita ja aikaa vieviä. Niiden läpiviemiseen tarvitaan myös kokemusta ja ammattitaitoa, joita ei voi edellyttää järjestöjen projektihenkilöiltä ja vastaavilta toimijoilta. Mitä lähemmäs SROIn käyttö menee sosiaalitieteellisen tutkimuksen tekemistä, sitä todennäköisemmin avuksi tarvitaan koulutettu tutkija.

Vamlasin Ratko-SROIssa haettiin tutkimuslupia. Niiden haussa noudatettiin kuitenkin harkintaa sen suhteen, miten muodollisesti meneteltiin kunkin toimijaryhmän kanssa. Myös eettiset kysymykset otettiin pohdintaan, sillä SROIssa haastateltiin vammaisia ja muuten osatyökykyisiä. Asiassa käännyttiin niin tutkimuseettisen neuvottelukunnan (TENK) edustajan kuin Nuorisotutkimusseuran tutkimuseettisen toimikunnan sihteerin puoleen. Todettiin, että varsinaisia eettisiä ongelmia ei ollut, sillä haastateltavat olivat kaikki täysi-ikäisiä ja osallistuivat haastatteluihin vapaaehtoisesti.

SROI-malli perustuu vaikuttavuustutkimuksen muutosteoria-ajatteluun. Muutosteoria (theory of change) "kertoo organisaation tai projektin toimintaperiaatteen, järjen ja logiikan - sen, millä tavalla toiminta tuottaa haluttuja hyviä muutoksia kohteissaan" (Klemelä 2016, 68). Muutoksen teorian elementit kirjoitetaan SROI-menetelmässä niin sanottuun vaikutuskarttaan, joka on taulukkomainen esitys vaikutusketjusta kunkin sidosryhmän kohdalla. Vaikutusketjulla, joka sisältönsä puolesta on käsitteenä koko lailla synonyymi muutosteorian käsitteelle, voidaan kuvata kaaviolla, joka etenee havaitusta tarpeesta ja toiminnan tavoitteista sidosryhmän panostuksen ja syntyvien tuotosten ja tulosten kautta 
SROI-mallin rahallistettuun vaikuttavuuteen eli hyötyyn.

Vaikutuskartta laadittiin Excel-ohjelmalla. Kaikki sidosryhmien investointija hyötylaskelmat kannattaa suorittaa samassa tai erillisissä Excel-dokumenteissa ja lopputulokset linkata automaattisesti vaikutuskarttaan päivittyviksi. Tällaisen mekaniikan luomisella saa aikaan hallittavan kokonaisuuden, jolla säästää merkittävästi aikaa ja vaivaa, kun jotain pientä tai yhtälailla suurta pitää muuttaa yhtälöissä tai niiden sisältämissä suureissa.

Sidosryhmien haastateltavien löytäminen ei ollut aivan suoraviivainen ja helppo prosessi. Siinä oli harkinnanvaraisen otannan (Saumure \& Given 2008) ja lumipallo-otannan (ks. Morgan 2008) piirteitä. Vamlasin henkilökunnan avustuksella pyrittiin löytämään tasapainoinen joukko haastateltavia. Kun haastatteluissa oli päästy alkuun, haastateltavilta kysyttiin tietoja mahdollisista lisähaastateltavista.

Ongelmaksi muodostui, että löytyneet haastateltavat vaikuttivat likipitäen kaikki sellaisilta, että Ratko-toimet ja työllistyminen olivat onnistuneet heidän kohdallaan. «Epäonnistuneita», joita heitäkin kuului olevan, oli vaikea löytää tai saada mukaan tasapainoisemman tarkastelun mahdollistamiseksi.Tämä piti ottaa huomioon laskennassa ja johtopäätöksissä.

Eri syistä johtuen SROIn data ei useinkaan pysty täyttämään laadullisesti kovinkaan tiukkoja kriteerejä. Aineistoa voi olla niukalti saatavissa tai sen rakenne on hajanainen, koska erilaisia sidosryhmiä on paljon. Ennakointityyppisessä SROIssa varsinaista dataa ei välttämättä ole lainkaan, jos toimintaa ei vielä ole. Tällöin pitää etsiä dataa hyvin isolla haavilla erilaisista, mahdollisimman lähellä oman analyysin tilannetta olevista tapauksista tai yksittäisistä muuttujista. Jos omassa analyysissa on kymmenittäin erilaisia panoksia ja hyötyjä, tällainen etsimistyö on erittäin aikaa vievää. Kaikki nämä ongelmat ilmenivät Vamlasille tehdyssä SROIssa jossain määrin. Ratkon SROIn raportin laatimisaikaa oli runsaasti, mutta usein analyysin aikataulu voi olla tiukka. Puutteista huolimatta SROI-mallintamisessa joudutaan tekemään näennäisesti hyvinkin tarkkoja ja laskelmien kannalta merkittäviä päätelmiä lukumääristä, osuuksista ja niiden vaikutuksista investointeihin ja hyötyihin. Varsinkin jos analyysin tekijällä on tutkijakoulutus, tämä on omiaan synnyttämään jopa omantunnontuskia. Tärkeäksi keinoiksi epävarmuuden kontrolloinnissa muodostuu herkkyysanalyysi eli tuloksiin vaikuttavien tekijöiden muuntelu, jonka tarkoituksena on tutkia muutosten vaikutusten merkitystä tulosten kannalta. Epävarmuuden kontrollointia edesauttaa myös mahdollisuus keskustella ja neuvotella SROI-tiimin ja sidosryhmien kanssa tulosten tulkinnasta ja vaihteluvälistä.

Vamlasin SROI-analyysissa haastateltiin yhteensä 18 sidosryhmien edustajaa. Haastatellut kuuluivat neljään sidosryhmään: työllistettyihin, työllistäviin organisaatioihin, työhönvalmentajaosapuoleen ja Ratkon kehittäjiin Vamlasissa. «Sidosryhmän» yhteiskunta kohdalla arviointityöhön tarvittavat tiedot - Kelan työttömyysetuuksia, palkkatasoja ja veroprosentteja koskeva informatio kerättiin julkisista dokumenteista. Ratkon käyttäjäorganisaatioiden asiakkaita ei haastateltu. Käyttäjäorganisaatioita oli monta, niiden asiakaskunnat olivat heterogeenisia ja olisi aivan liian työlästä 
ja keinotekoistakin etsiä sellaisia asiakassuhteita, joiden avulla olisi voinut arvioida työllistettyjen vaikutusta asiakaskokemukseen. Periaatteellisella tasolla asiakkaiden sidosryhmä on kuitenkin tärkeä, joten se jätettiin SROI-malliin näkyviin.

Haastattelut olivat muodoltaan puolistrukturoituja. Haastattelujen edistyessä todettiin, että voisi olla hyödyllistä, jos osaan keskeisistä kysymyksistä pyydettäisiin haastattelussa vapaamuotoisten arvioiden lisäksi myös numeeriset tai monivalintatyyppiset vastaukset. «Mittausten» avulla olisi mahdollista saada täsmällisempi tulkinta joihinkin keskeisiin kohtiin, jotka SROI-analyysissa jouduttiin joka tapauksessa kvantifioimaan eli määrällistämään. Numeeriset mittarit lisättiin jäljellä olevien haastattelujen kysymyssarjoihin, ja jo haastateltuihin henkilöihinkin otettiin uudestaan yhteyttä ja pyydettiin heiltä vastaukset näihin uudelleen muotoiltuihin kohtiin.

Mittareiden lisäksi piti etsiä myös proxyt eli korvikemuuttujat. Niiden avulla mittaustulokset rahallistetaan. Proxyjen keksiminen ei Vamlasin SROIssa ollut sinällään hankalaa. Nykyisin on helppo käyttää internetin hakugeneraattoria erilaisten vaihtoehtojen kartoittamiseksi. Hankalampaa on hyvien ja tasapainoisten proxyjen keksiminen tai luominen. Tasapainoiseksi korvikemuuttujaksi voidaan ymmärtää sellainen, joka rahallistaa mitattavan ilmiön validisti ja joka on tulokseltaan oikeaa suuruusluokkaa suhteessa koko tutkittavan toiminnan kokonaisuuteen. On aivan eri asia määrittää vaikkapa mielenterveyden kohentumisen arvoa itsehoito-oppaan kauppahinnalla kuin säännöllisen psykoterapian kustannuksilla. Proxyn valinta on toimi, jolla pystyy «pelaamaan».Valitsemalla suuriarvoisen proxyn hyötypuolelle saa SROI-osamäärään ison osoittajan. Tällainen ei tietenkään ole hyväksi menetelmän uskottavuuden kannalta. Proxy-pankit eli koeteltujen ja hyväksi havaittujen, mitatun toiminnan rahallisten vastineiden kokoelmat, olisivat olennaisia, jotta rahallistamisesta saataisiin rutiininomaisempaa ja voitaisiin saavuttaa jopa jonkinlaista erilaisten organisaatioiden toiminnan vertailukelpoisuutta.Yksittäisten rahallistavien proxyjen rinnalle pankkeihin olisi hyvä rakentaa summamuuttujina «proxy-koreja» erilaisten ilmiöiden rahallistamisen realistisemmaksi pohjaksi. Kyseessä olisivat usean osamuuttujan kombinaationa laaditut rahallistajat eri ilmiöille - vähän samaan tapaan kuin kuluttajahintaindeksi toimii. Koreja muuttujina käyttämällä kukin soveltaja voisi myös muuttaa siihen sisältyvien osatekijöiden painoarvoja vastaamaan paremmin omaa toimintaa.

SROI-raportin kirjoitustyössä on luontevaa yhdistää tietyt SROI-vaiheet tekstissä, jotta niistä saadaan johdonmukainen ja vaivattomasti luettava kokonaisuus. Sen asemesta, että kirjoitustyössä kokonaisuutena olisi edetty mallintamisen vaiheiden järjestyksessä, Vamlasin SROIn raportissa kirjoitettiin auki vaikutustekijä kerrallaan kaikki mallintamiseen liittyvät asiat. Kukin tekijä käsiteltiin kokonaisuudessaan yhdessä ja samassa paikassa. Näin esityksestä saatiin tiivis ja informatiivinen ilman, että lukiessa pitäisi jatkuvasti liikkua tekstin osasta toiseen ja etsien tiettyyn vaikutustekijään liittyviä mallintamisvaiheita. 


\section{LASKEMISEN KIEMUROITA}

Ratko-menetelmän SROIhin liittyi ehkä poikkeuksellisenkin paljon suoraa ja "raakaa" laskemista. Tämä johtui siitä, että analysoitiin toimintaa, johon kuului kohderyhmän, osatyökykyisten, tekemää palkkatyötä. Asiaa helpotti tietenkin se, että SROI on arviointia.Täten palkka- ja vero-osuuksien ynnä muiden tietojen ei tarvitse olla aivan sentilleen, kunhan suuruusluokka on oikea.

Niin sanottujen vaikuttavuutta vähentävien tekijöiden, eli turhan panostuksen, muun toimijan ansioiden, syrjäyttämisen ja vaimenemisen, kohdalla päätiin analyysissa aika helpolla, koska osatyökykyisten ja vammaisten työllistäminen on melko omanlaistaan toimintaa. Ratkon SROI-laskelma koski kahta vuotta. Piti siis suorittaa diskonttausta. Korkona käytettiin kansainvälisesti usein standardina käytettyä 3,5 \% vuosittaista diskonttokorkoa. Tämä käytäntö vaatisi kuitenkin täsmentämistä, koska on vaikea sanoa, onko tuo korko oikeastaan perusteltu ja mitä korkoa Suomen oloissa pitäisi soveltaa.

SROI-luvun arvoksi Ratko-menetelmän käytölle saatiin 3,0. Laskennallisesti rahallistetut yhteiskunnalliset hyödyt kattoivat siis rahallistetut investoinnit kolminkertaisesti. Tämä oli kuitenkin vasta lähtökohta argumentaatiolle, jota lähdettiin tekemään herkkyysanalyysin yhteydessä. Vamlasissa haluttiin sanoa jotain siitä, millä tavalla Ratko-menetelmä asemoituu muun vammaisten ja osatyökykyisten työllistämistoiminnan rinnalle. Vertailevaa asetelmaa tai aineistoa ei kuitenkaan voinut rakentaa tai saada. Tilanne, jossa SROI-työn tilaajalla on runsaasti odotuksia siitä, mitä tietyn kohteen tutkimisella voidaan saada selville, lienee varsin yleinen arviointitutkijoiden keskuudessa. Vamlasin SROIssa keksittiin eräänlainen kiertotie, jolla pystyttiin edes varovaisesti simuloimaan Ratko-tyyppisen menetelmän hyötyjä. Tämä tehtiin siten, että eri sidosryhmien kaikkien investointien ja hyötyjen joukosta poimittiin ne, joiden katsottiin olevan erityisen «Ratko-herkkiä», toisin sanoen sellaisia, että Ratkoa käyttämällä juuri niihin pystyttiin vaikuttamaan. Tällaisia olivat esimerkiksi töiden sujuvoituminen koko organisaatiossa sekä vakinaisten henkilöiden työn mielekkyyden lisääntyminen, kun työnkuva on selvempi ja silpputyötä karsittu. Näiden muuttujien arvoja muutettiin herkkyysanalyysissa ja tehtiin päätelmiä siitä, kuinka paljon Ratkolla voisi olla vaikutusta verrattuna työllistämiseen, jossa ei (kuvitteellisesti) olla kiinnostuneita sosiaalisista ja psyykkisistä hyödyistä sekä työllistämiseen, jossa kiinnostus näihin hyötyihin on kokonaisuutena ja karkeasti arvioiden vähäisempää.

\section{LOPUKSI}

SROI on varsin työläs metodi käyttää. Se on kuitenkin menettelyltään johdonmukainen, eikä mikään siihen liittyvistä vaiheista edellytä suorittajalta erikoiskykyjä. Soveltaja tulee toimeen yhteen-, vähennys-, kerto- ja jakolaskulla.

On tärkeää huomata, että SROIn runkona on yleisesti tunnettu ja paljon käytetty ajatus vaikutusketjusta. Vaikutusketjuajattelun intuitiivisuus ja monikäyttöisyys madaltaa kynnystä ottaa SROI käyttöön. Jos vaikutusketjun ajatus ole aiemmin ollut tuttu, sen oppii viimeistään SROIsta ja sen jälkeen sitä 
voi hyödyntää kaikessa arviointihenkisessä ajattelussa menetelmästä riippumatta.

On tärkeää tiedostaa myös, että SROI on evaluaatiota eli arviointia, ei tieteellistä tutkimusta. Patton (2017) kirjoittaa, että tutkimustieto toki vaikuttaa arviointitiedon laatuun, mutta tieteellisen tutkimuksen ja arvioinnin tavoitteet ovat erilaiset. Tutkimus pyrkii tuottamaan tietoa siitä, millainen maailma on ja miten se toimii, evaluaation avulla taas selvitetään, toimiiko tietty ohjelma tai projekti tavoitteidensa mukaisesti.

Käytännön SROI-työskentelyn kautta sekä työskentelystä kirjoitettuja kuvauksia lukemalla menetelmästä ja sen käytöstä voi tehdä havaintoja, jotka eivät helposti tule esille pelkästään SROIsuoritusohjeita ja raportteja lukemalla. Puheenvuoron loppuun on vielä tiivistetty muutamia keskeisiä yleisen tason huomioita. Huomiot on kirjoitettu erityisesti, mutta ei yksinomaan, Vamlasin SROI-mallityöskentelyn pohjalta.

SROIssa tarvitaan hyviä tiedonkeruutaitoja ja ymmärrystä tulosten yleistämiseen liittyvistä rajoituksista. Tiedonkeruun vaativuutta ehkä hieman vähätellään SROI-kontekstissa, sillä tieteellisestä koulutuksesta on datan keruussa iso hyöty. Tiedonkeruutaitojen vaatimus nostaa maallikon kynnystä menetelmän käytölle ja lisännee professionaalisten taitojen kysyntää.

SROIn tulosten uskottavuus on usean tekijän funktio. SROIta joudutaan tekemään vaihtelevalla määrällä dataa ja kirjoittajan kokemuksen mukaan evidenssi voi joskus olla varsin ohutta. Niinpä SROIssa argumentoitujen, organisaati- on tai muun toimijan tuottamien hyötyjen uskottavuus on realistisesti arvioiden kiinni myös siitä, mikä tai kuka väitetyt hyödyt tuottaa ja kuka niitä arvioi.

Eettiset pohdinnat ovat SROIssakin asiaankuuluvia, varsinkin kun analyysi melko tyypillisesti tehdään järjestökontekstissa, jossa toiminnan kohderyhmänä on usein epäedullisessa asemassa olevia ihmisiä. Vaikka SROI ei olekaan varsinaista tutkimusta, myös SROI-datan keruussa tarvitaan tutkimusluvat, jos kerätään arkaluontoista tietoa. Tutkittavilta tarvitaan myös allekirjoitukset suostumuslomakkeisiin.EU:n tietosuoja-asetus ja tietosuojaan liittyvä kansallinen lainsäädäntö asettavat omat vaatimuksensa henkilörekisterien käsittelyssä. Tällaiset näkökohdat eivät ainakaan vielä saa riittävästi huomiota SROI-ohjeistuksissa.

SROI-oppaissa ja esimerkkiraporteissa on vähän tai ei lainkaan ohjeita ja esimerkkejä sellaisten laskentatilanteiden käsittelyyn, joihin liittyy palkkoja, palkan sivukuluja, verotusta tai erilaisia sosiaalitukia. Näiden erien laskeminen on vaativaa eikä SROI-menetelmän käytön hengen mukaista oikein ole tehdä laskemisesta liian pikkutarkkaa. Tarvittaisiin koostettua ohjeistusta «vaikeista» tilanteista (proxy-pankkien rinnalle).

Sekä SROI-tiimityöskentelyssä että SROI-analysoijan vuorovaikutuksessa sidosryhmäedustajien kanssa vaaditaan vaivannäköä. Tiedonkeruun prosessi muodostuu helposti hermeneuttistyyppiseksi eli asteittain syveneväksi ja laajenevaksi, kun vaikka organisaation ulkopuolinen analysoija lähtee tutkimaan itselleen ennalta tuntematonta toimintaa järjestössä, jonka toiminta on omanlaistaan ja jolla ei ole systemaatti- 
sesti dokumentoitua historiaa ja täsmällisiä toiminnan kuvauksia. Jos SROItiimiltä haluaa kommentteja analyysissa tehtyjen ratkaisujen järkevyyteen, täytyy olla aikaa ja resursseja tarkistuttaa niitä. SROI-tiimin pitää sitoutua lukemaan ja kuuntelemaan kysymykset sekä myös vastaamaan niihin. Sidosryhmien edustajilta kannattaa pyytää lupa palata asiaan, jos esille nousee myöhemmin lisäkysymyksiä. Ihmisille voi joutua soittelemaan ja sähköpostittelemaan useitakin kertoja, kun tarkistaa asioita.

Tämän puheenvuoron kirjoittajalta on kysytty usein, eikö SROIta voi tehdä jotenkin «kevyemmin»: vähemmän työläästi ja aikaa vieden. Periaatteessa tällainen kysymys on sikäli ongelmallinen, että on vaarallista yrittää päättää etukäteen, mitä priorisoidaan. Valintoja on ehkä helpompi tehdä kestävästi silloin, kun on jo jonkin matkaa edetty kohteen SROI-mallintamisessa ja saadaan vahvempi käsitys siitä, mikä on keskeistä. SROIn käyttöönotto ja käyttö ovat molemmat oppimisprosesseja.

\section{VIITE}

1 Kirjoittaja on ollut yhtenä kouluttajana SOSTEn koulutuskiertueella opettamassa SROIn käyttöä, ja koulutukset ympäri Suomen ovat olleet erittäin suosittuja.

\section{KIRJALlisuUS}

Freeman, R. Edward (1984) Strategic Management. A Stakeholder Approach. Boston, MA: Pitman.

Hietala, Outi \& Sippola, Aulikki \& Riipinen, Markku \& Lampinen, Pauliina \& Nevalainen, Marja (2015) Kaikille sopi- va työ ja työyhteisö. Tutkimus- ja kehittämishankkeen loppuraportti 1.8.2015. Helsinki:Vamlas. https://www.vamlas.fi/ wp-content/uploads/2017/09/kaikillesopiva-tyo.pdf Luettu 1.4.2017.

Klemelä, Juha (2016) Järjestöt, vaikuttavuus \& raha-SROI-arviointimenetelmä. Helsinki: SOSTE Suomen sosiaali- ja terveys ry. https://issuu.com/soste/docs/ sroi-arviointimenetelm__soste Luettu 1.4.2017.

Klemelä, Juha (2018) Vaikuttavuutta työn muotoilulla - Ratko-mallin analyysi Social Return on Investment-menetelmällä.Helsinki: Vamlas. https://www.researchgate. net/publication/331062629_VAIKUTTAVUUTTA_TYON_MUOTOILULLA_-_Ratko-mallin_analyysi_Social_ Return_on_Investment_-menetelmalla Luettu 4.3.2019.

Morgan, David L. (2008) Snowball Sampling. Teoksessa Lisa M. Given (toim.) The Sage Encyclopedia of Qualitative Reseach Methods, 815-816. http://dx.doi. org/10.4135/9781412963909.n289 Luettu 3.2.2018.

Nicholls, Jeremy \& Lawlor, Eilis \& Neitzert, Eva \& Goodspeed, Tim (2012) A Guide To Social Return On Investment. 2. laitos. The SROI Network. http://www. socialvalueuk.org/resources/sroi-guide/ Luettu 26.8.2013.

Patton, Michael Quinn (2014) Evaluation Flash Cards. Embedding Evaluative Thinking in Organizational Culture. St. Paul, Minnesota: Otto Bremer Trust. https://ottobremer.org/news_stories/ evaluation-flash-cards/ Luettu 6.4.2018.

Saumure, Christie \& Given, Lisa M. (2008) Nonprobability Sampling. Teoksessa Lisa M. Given, Lisa M. (toim.) The Sage Encyclopedia of Qualitative Reseach Methods. http://dx.doi. org/10.4135/9781412963909.n289 Luettu 3.2.2018.

Vamlas (2011) Ratko-projektin RAY-avustushakemus. 16.5.2011. 